DOI: $10.15290 /$ rtk.2018.17.2.02

iD 0000-0002-0566-9534

Rev. Mieczystaw Olszewski

Papieski Wydziat Teologiczny w Warszawie

\title{
Blessed Michael Sopocko: A Zealous Pastor
}

Bl. Fr. Michael Sopocko is a fascinating figure, particularly because of his zealous involvement in everything that he did, especially in his pastoral ministry. This article discusses Bl. Michael Sopocko's pastoral achievements based on three biographical and chronological stages of his life, pastoral activity, and academic work. The first stage involves his early life in his family home as well as his work at the parish in Taboryszki, where he served until 1918 when he went to study in Warsaw. The second stage took place when he returned to Vilnius after completing his intermittent studies at the University of Warsaw (from 1918 until December 8, 1924) and until he met St. Faustina who introduced him to the mystery of Divine Mercy in 1933-1934. In the third phase of Bl. Michael Sopocko's pastoral and academic ministry, the mystery of Divine Mercy dominated his thoughts and views on both the Church's activities and pastoral ministry.

Key words: family home, parochial vicar, university studies, World War I, military chaplain, spiritual father, professor, Stefan Batory University, confessor, educator, building up the Church, Divine Mercy, Vilnius, Warsaw, Bialystok.

Fr. Michael Sopocko's very intense work in the parish where he sought the good of the faithful was characterized by the beautiful traits that he had developed while living with his family. Michael Sopocko grew up in a family home that was permeated by a sense of deep piety. The entire Sopocko family prayed together daily, sang religious songs, and participated with great devotion in the services at their parish church. These practices were their "daily bread." Fr. Michael Sopocko later wrote in his Memoirs about who and what influenced his vocation to the priesthood and his religious fervor: 
Bl. Michael Sopocko
I began to think about dedicating my life to the service of God as a child growing up in a religious environment. Every day my father led family prayer; we frequently chanted the Liturgy of the Hours; we sang seasonal songs, especially during the winter; we rode in the carriage to the parish church which was located $18 \mathrm{~km}$ away [from our home]; we participated in family celebrations (baptisms, funerals, burials) at home and at our neighbors' homes, during which we sang religious songs and talked with neighbors predominantly about religious topics. All of these things influenced me subconsciously as a child and motivated my desire to serve Him, Who I did not know, but Whom I worshiped, asked for forgiveness, and beseeched for grace. ${ }^{1}$

Fr. Michael was a very religiously disposed priest. In his Memoirs he wrote that his father really wanted to educate his children, but their meager finances made it impossible until 1901-1902 when he sent two of his sons-Michael and his younger brother Peter-to a local grammar school in Zabrzez. Michael wrote the following about his experiences there:

My year-long stay in Zabrzez (1901-1902) was very memorable not only with regard to school where the teacher taught poorly, but also because there was a parish church nearby at which I received my First Holy Communion (1986), served at the Holy Mass, accompanied the organist by singing the Little Office of Our Lady, and visited each day. At that time, Fr. Jan Kunicki replaced the good Fr. Sokolowski. Fr. Kunicki was extremely eloquent and had true apostolic zeal; he was very moving and directly changed the faithful's views and habits. His fiery sermons captivated his listeners and influenced me greatly - so much so, that I decided never to drink alcohol or visit an Orthodox church for the rest of my life. His inspired attitude as he stood at the ambo or altar, his fervor in hearing confessions, and his concern for fostering the proper worship of God suggestively influenced my desire to imitate him in the future and to become a priest." 2

Michael Sopocko's pastoral activity began in September 1914 after he was ordained a priest and assigned to serve as a vicar in the parish in Taboryski, which was located 40 kilometers from Vilnius. Here he was greatly involved in pastoral ministry for the good of his parishioners. When performing the pastoral duties assigned to him by his pastor Fr. Lacki (celebrating Mass, giving homilies, visiting the sick), Fr. Sopocko discovered that the parishioners had other needs, which he immediately strove to remedy by providing catechesis for children and giving catechetical homilies which, as he noted, were

$1 \quad$ M. Sopoćko, "Wspomnienia z przeszłości," in WKAB 13, no. 2 (1985), pg. 84. 
well attended. Despite his pastor's initial resistance, Fr. Sopocko was able to create a youth choir that sang the Rosary, prayers, pious devotions, and even the Holy Mass by Haller on Christmas. During Lent, Bl. Michael Sopocko Fr. Sopocko heard confessions in order to prepare the parishioners for Easter. Fr. Sopocko quickly noticed that the parishioners were insufficiently prepared to receive the sacrament of Penance, so he invited them to arrive 30 minutes early so that he could prepare them well for Confession.

Parishioners were amazed at Fr. Sopocko's pastoral wisdom and fervor, and they perceived how he sacrificed his time and health in order to serve them in the best way. In May 1915, he began gathering approximately 500 children to teach and prepare them for their First Holy Communion. In addition, many older parishioners attended and listened closely to Fr. Sopocko's catechesis based on Fr. Roch Filochowski's catechism. ${ }^{3}$

Bl. Michael Sopocko also cared for the spiritual lives and material needs of his parishioners Since many of the villages were located far away from the parish church in Taboryski, including Miedniki Krolewskie (15 km away) and Onzadowo (17 km away), it was difficult for the inhabitants of those villages to come to their home parish, and it was also difficult for Fr. Sopocko to visit them, particularly the sick. Consequently, Fr. Sopocko saw to it that a barn in Miedniki that was part of his previous parish and had been liquidated by the Russian occupational authorities after the January Uprising was converted into a chapel for the soldiers and the faithful. The makeshift chapel was consecrated on August 17, 1916, and from then on it served as a house of worship where Holy Mass was celebrated every Sunday and the other sacraments were offered. Fr. Sopocko also arranged for a makeshift chapel to be erected in Onzadowo where the inhabitants had attempted to ask for permission to build a church before World War I began. The outbreak of the war, however, made it impossible to fulfill the desires of the inhabitants of Onzadowo and those who lived in the surrounding areas. Therefore, with the help of the faithful, Fr. Sopocko saw to it that a temporary chapel was established in an abandoned granary in the countryside of Tarasowszczyzna. This chapel was consecrated for the benefit of the faithful on October 28, 1917. ${ }^{4}$

In addition to his pastoral work, Fr. Sopocko also strove to increase the level of education for those residing in the places under his pastoral care. For example, he began by organizing grammar and high schools

\footnotetext{
3 See Ibid, pgs. 99-100.

$4 \quad$ Ibid, pg.107.
} 
Bl. Michael Sopocko

by converting old abandoned buildings formerly used for military operations. However, since there were not enough teachers to educate the children and youth in the two-class schools, the number of which had increased to 20 by Easter 1916, Fr. Sopocko and a sympathetic German inspector prepared a two-month long course in methodology in Bialy Dwor for 45 teachers from the County of Vilnius in the summer of 1916. ${ }^{5}$ Fr. Sopocko's efforts to improve the education system were very successful. By the end of 1917, he had organized thirty-six schools in the areas where he served pastorally. ${ }^{6}$

All of Fr. Sopocko's efforts to improve education and provide pastoral care demonstrate his great priestly fervor and desire to lead people to God. His astonishing output reveals how a dedicated priest can effect so much good in the spiritual and intellectual lives of others. Bl. Michael Sopocko's involvement was always pragmatic, and he always took advantage of opportunities to take on certain works. At times, however, his fervor overcame what seemed to be hopeless difficulties, and the fruits of his efforts spoke (and continue to speak) for themselves.

\section{A Military Chaplain and University Student}

Fr. Sopocko's great dream was to deepen his own knowledge in order to better serve others. He wrote of this dream in his Memoirs:

[...] among other things, my studies were one of the my main callings. However, because of my other duties, I could not dedicate myself solely to it [...] When possible, I took advantage of every opportunity to do continue [my education].

He also recorded that he took important steps to achieve this goal by privately studying English and French and of refreshing his knowledge German, which he had learned in school. ${ }^{7}$

While Fr. Sopocko was serving at the parish in Taboryszki, the German occupiers threatened to imprison him because of his educational efforts during the ongoing war. In order to avoid this at all costs, Fr. Sopocko went to Warsaw in 1918 with the intention to pursue further studies at the university. Fr. Sopocko's desire to study was motivated by a new era that was unfolding in Poland as well as the possibility that Poland would become independent at the end of World War I:

\footnotetext{
Ibid, pg. 104.

Ibid, pg. 109.

Ibid, pg. 120.
} 
Everything presaged that a new order was being established-an order for which I had to properly prepare myself by making up for my lack of knowledge in certain areas, particularly in pedagogy. With time, the thought of going to Warsaw for further studies developed. ${ }^{8}$

Fr. Sopocko noted in his diary:

... during the first days of October of 1918 [October 6], I was in Warsaw. For the time-being refugees were being quarantined here at Gdański Station. It was Sunday, and I asked the Commander to let me go into the city to celebrate Holy Mass. After hesitating for a moment, the Commander gave me permission to go all the way to Warsaw. I arrived to the church of the Holy Cross, where I stopped at the dormitory next to the Department of Theology of the newly-opened university. ${ }^{9}$

In this way, Fr. Sopocko achieved his great dream and he was able to pursue his academic studies, which he considered one of "the greatest tasks of his life," as he called it. ${ }^{10}$

The war continued, many students enrolled in the military, and lectures at the university were put on hold. On January 29, 1919, Fr. Michael Sopocko was summoned to serve as a military chaplain. The Field Bishop Stanislaw Gall appointed Fr. Sopocko to the Vilnius Rifle Regiment of the Belarusian-Lithuanian Division, which was stationed in Vawkavysk. While visiting the military troops, especially the wounded soldiers, Fr. Sopocko celebrated Mass and heard confessions. Because of his efforts, Fr. Sopocko became weaker; and Field Bishop Stanislaw Gall ordered him to go to Zakopane to rest. After this period of respite, Fr. Sopocko returned not to the Eastern Front, but rather to Warsaw where he was assigned to serve as the chaplain of the Kosciuszko Engineer Training Camp. In addition, on October 16, 1919, Fr. Sopocko also began academic studies at the University of Warsaw, where he specialized in moral theology and attended lectures on law and philosophy. While it was very difficult for Fr. Sopocko to simultaneously study and serve as a military chaplain, he amazingly managed to do both.

While performing his duties as a military chaplain and pastorally ministering to the soldiers, Fr. Sopocko was also involved in social work related to those under his care. He wrote the following in his Memoirs:

\footnotetext{
$8 \quad$ Ibid, pg. 111.

9 Ibid; Dziennik, edited and with an introduction and footnotes by H. Ciereszko, Bialystok 2012, $2^{\text {nd }}$ Edition, pgs. 77-78.

Ibid, pg. 99.
}

Bl. Michael Sopocko 
Bl. Michael Sopocko

I lived in housing for the theology students on ul. Tragutta 1. After Mass, I went to lectures. Then I ate lunch and went to the hospital and the departments entrusted to my pastoral care. In addition to leading devotions and talks for the soldiers, I was involved in social work, including: organizing the Fraternal Aid for soldiers [...], being in charge of the inn for the soldiers, and organizing a school for orphans of war. These students learned to play different instruments and then became part of the orchestra."

In 1924, after Fr. Sopocko had obtained his master's degree and certification to educate teachers, he returned to Vilnius where he became the Director of Pastoral District, which included the Garrisons in Vilnius, Nowa Wilejka, Podbrodzie, and Berezwecz, for a total of 16 regiments. ${ }^{11}$ Since there were so many soldiers, it was difficult for them to participate in Sunday masses. Fr. Sopocko took this need to heart and began efforts to build a garrison church. Having overcome huge financial and organizational difficulties, he achieved his goal, and the Church of St. Ignatius in Vilnius, which Fr. Sopocko worked so hard to have built, was consecrated on September 26, $1929 .{ }^{12}$

Fr. Sopocko always tried to ensure that the faithful had good and improved access to churches, and his experiences preparing places of worship for the faithful when he was serving as a parochial vicar in Taboryski bore much fruit in his later pastoral ministry. For example, as was mentioned before, Fr. Sopocko renovated St. Ignatius church so that it could serve as a place of worship for the troops and local civilians. Not only did Fr. Sopocko's concern for places of worship arise out of his desire to ensure the good of the faithful, but also from his keen observation that churches needed to be accessible and, therefore, erected in a good location. In the article Centrum i peryferia [The Center and Periphery], which was published in "Wiadomości Archidiecezji Wileńskiej" [The Archdiocese of Vilnius News] in 1933, Fr. Sopocko substantiated the necessity to create new parishes in order to make them more accessible to the faithful. According to Fr. Sopocko, the closer the parishes are to the faithful (and, therefore, the easier they are to access), the easier it is for the faithful to deepen their religious lives. For this reason, Fr. Sopocko argued that it was necessary to adapt a network of parishes to the needs of the faithful. ${ }^{13}$ Fr. Sopocko even specified the ideal distances between peoples' homes and churches; specifically, he proposed that churches located in the

\footnotetext{
$11 \quad$ See ibid, pg. 109.

12 Ibid, pg. 129.

M. Sopoćko, Centrum i peryferia, WAW 7(1933), pg. 182.
} 
countryside should be no more than $6 \mathrm{~km}$ away from local inhabitants and that churches located in the city should be no more than $1.5 \mathrm{~km}$ away from inhabitants. ${ }^{14}$

Fr. Sopocko sought to build new churches in Bialystok as well, since the city had been greatly destroyed during the war and because its development and population grew rapidly after the war. Needless to say, at that time people were in great need of places of worship, and Fr. Sopocko observed and desired to address this need. For example, the Missionary Sisters who lived at ul. Poleska 42 had a chapel to which they invited Fr. Sopocko to celebrate Mass. However, around 100 people came to participate in these masses, and they had to stand outside of the chapel because there was not enough space inside. Observing the faithful's interest in participating in the different devotions near their homes, Fr. Sopocko considered and then carried out the expansion of the little chapel after overcoming the difficulties posed by the city authorities. ${ }^{15}$ Another example of Fr. Sopocko's concern for the good of the faithful was manifested in his efforts to have a convent and chapel built for the Sisters of the Merciful Jesus, which would be accessible to the faithful who lived in the vicinity that had been pastorally neglected because the parish church, St. Roch's, was located far away. Fr. Sopocko reached an agreement with some individuals who owned a half-hectare of the plaza on ul. Celowniczna where he hoped to erect a building that could serve as a convent and chapel. The local authorities, however, absolutely forbid Fr. Sopocko from establishing a house of worship, and ordered that what had been built thus far be demolished. ${ }^{16} \mathrm{Fr}$. Sopocko encountered the same situation in in Nowe Miasto, which was located in the vicinity of Bialystok. From a pastoral point of view, Fr. Sopocko felt that another chapel was necessary for the inhabitants of this town because the nearest churches-St. Stanislaw's and the parish church-were located more than $2.5 \mathrm{~km}$ away from the faithful. Consequently, Fr. Sopocko made every effort to secure a place in the town square located at ul. Wiejska 41 to build a future church and establish a parish. All of his efforts, however, proved futile because the local authorities created a lot of obstacles and the Church leadership neglected the issue. ${ }^{17}$ Although Fr. Sopocko was not always successful in applying for places to erect new churches that the local faithful could access easily and at which they could worship, he will $14 \quad$ Ibid, pg. 184.

15 See M. Sopoćko, Wspomnienia z przeszłości, WKAB 14(1986) no. 1, pgs. 115-116.

$16 \quad$ Ibid, pgs. 116-117.

17 Ibid, pgs. 117-118. 
Bl. Michael Sopocko

always be remembered as a priest who was very concerned for the good of the faithful and who had a deep understanding of the needs of the Catholics in the city of Bialystok.

\section{Ministry in the Seminary in Vilnius and the Provision of Spiritual Direction to Religious Sisters}

Fr. Michael Sopocko took his pastoral ministry very seriously and devoted himself wholeheartedly to whomever he served, whether it be soldiers, priests, or religious sisters. Archbishop Romuald Jalbrzykowski appointed Fr. Michael Sopocko as the spiritual father of the Archdiocesan Seminary of Vilnius on August 8, 1927. In his humility, Fr. Sopocko wrote about his reservations about accepting the appointment:

I valued the role of the spiritual father in the formation of priests too highly to consider myself qualified to fulfill such a role. Therefore, I humbly expressed my gratitude for this opportunity, but clarified that I am neither worthy nor sufficiently prepared for the position, and that I cannot recklessly leave my appointment as pastor of the garrison, etc. ${ }^{18}$

The archbishop did not revoke Fr. Sopocko's nomination, however, and, after accepting the position, Fr. Sopocko wrote the following about what he thought it meant to be a spiritual father:
A spiritual father should be a good priest, a man of proven virtue and honesty, a dignified man, one who is endowed with every kind of vir- tue. [He should also be] capable of encouraging the students in every way to be pious and virtuous through his own words and example, of loving them in God, of respecting and trusting them and, in this way, of gaining their trust. ${ }^{19}$

In addition to his classes at the seminary, Fr. Sopocko was still involved in a variety of pastoral areas. From a very young age, Fr. Sopocko saw how alcoholism was a huge threat to faith and religious life. After hearing Fr. Lacki's homilies, he vowed never to drink alcohol. For these reasons, he worked very hard to combat alcoholism, particularly amongst the faithful and clergy. When working with the students at the seminary, Fr. Sopocko organized the Abstainers' Club, to which $60 \%$ of his pupils belonged. ${ }^{20}$ This work led Fr. Sopocko to found the Abstainers' Club for Priests. To this end, he organized a few meetings

\footnotetext{
18 M. Sopoćko, Wspomnienia z przeszłości, WKAB 13(1985) no. 4, pg. 85.

19 Ibid.

$20 \quad$ Ibid, pg. 108.
} 
for members each year as well as an annual meetings at which invited speakers from outside of the archdiocese would give speeches. ${ }^{21}$ Three elements dominated Fr. Sopocko's religious and pastoral activities to promote abstinence: prayer, self-study, and outside influences. ${ }^{22}$

Fr. Sopocko's important efforts to promote sobriety brought him to Bialystok to create sobriety circles among students and priests. Concerned about the sobriety of the Polish nation, he examined the problem of addiction and the affects of drunkenness on schoolchildren and youth during his studies in Warsaw in the spring of 1924. Specifically, Fr. Sopocko conducted a study amongst children in grammar and high school to determine the effects of alcohol on their academic achievement. Fr. Sopocko subsequently wrote a thesis entitled "Alcoholism and School-Aged Children" which was based on his findings. His work was then published that same year in "Przegląd Pedagogiczny" [The Pedagogical Review]. His research and work was so highly esteemed that Fr. Sopocko was often invited to give lectures on the topic of battling alcoholism. ${ }^{23} \mathrm{Bl}$. Michael Sopocko continued his fight against alcoholism in the Archdiocese of Bialystok within secular society as well.

Fr. Michael Sopocko also worked toward enriching the religious education of the Polish intelligentsia. When the Koło Inteligencji Katolickiej [The Catholic Intelligentsia Circle] was founded at the Catholic University of Lublin, Fr. Sopocko immediately began organizing the same kind of group in Vilnius. Thanks to the help and involvement of Fr. Jozef Czerniawski, PhD, and Professor Waclaw Staszewski, the Koło Inteligencji Katolickiej was established as an affiliate of the same group in Lublin. The group had a few departments, including the department responsible for spiritual life, the members of which met at Fr. Sopocko's home. According to Fr. Sopocko, primarily professors from the Stefan Batory University and teachers from the high schools who taught mostly the natural and technical subject belonged to this group. ${ }^{24}$

The great concern for increasing the laity's religious knowledge and awareness that Fr. Sopocko had already begun to manifest in Vilnius became very evident in Bialystok. In 1951, Fr. Sopocko contributed to the creation of courses and lectures for the laity that took place in the so-called "old church" next to the cathedral in Bialystok. These

${ }_{21} \quad$ See T. Żdanuk, Działalność abstynencka księdza Michała Sopoćki, WKAB 18 (1990), pgs. 100-113.

$22 \quad$ Ibid, pg. 103.

$23 \quad$ M. Sopoćko, Wspomnienia, WKAB 13(1985) no. 3, pg. 108.

$24 \quad$ Ibid. 
Bl. Michael Sopocko

courses corresponded to the programs offered in the Instytuty Wyższej Wiedzy Religijnej [The Institutes of Advanced Religious Learning)]; however, Fr. Sopocko refrained from using this title in order to avoid provoking the communist authorities. These courses began in 1951 and continued for a long time even after Fr. Sopocko retired in 1962. Then, they suddenly ceased. The graduates of these classes took exams in specific areas and, if they passed, received certificates in fields of theology, including: theology, ethics, and the history of the Church. ${ }^{25}$

Fr. Sopocko also ensured that religious education teachers, meaning catechists, received proper formation. In his Memoirs he wrote about the difficulties that the communist leadership in Poland caused the Church as they aggressively strove to secularize Poles. In particular, the new school authorities forbade students to come to observe lessons in religion and conduct mock lessons, which were necessary for catechizing children and youth. By the end of the $1940 \mathrm{~s}$, communist authorities removed religion classes from Polish schools altogether. Catechesis, therefore, had to take place at so-called "catechetical locations" outside of school in sometimes fatal conditions. Religious education teachers were necessary to meet the needs of all of the youth and children. Therefore, Fr. Sopocko organized and offered catechetical courses for religious sisters and the laity in order to prepare them to serve as future catechists. ${ }^{26}$ Fr. Sopocko himself mentioned that he organized a few such courses with the help of professors and priests as well as older catechists, and these courses took place in the old parish church from 1951-1958. ${ }^{27}$ Bishop Henryk Ciereszko pointed out, however, that the "Calendar of Bl. Michael Sopocko's life" lists slightly different dates and that Archbishop Romuald Jalbrzykowski assigned Fr. Sopocko to organize a catechetical course for religious and the laity as an ongoing pastoral work that lasted a few years. ${ }^{28} \mathrm{How}-$ ever, the Curia's Catechetical Archive of the Blessed Michael Sopocko Center for Pastoral and Catechetical Formation located in Bialystok contains certificates indicating that several individuals completed the catechetical course on October 5, 1959. These certificates were issued by the Archdiocesan Curia of Bialystok and signed by Fr. Sopocko as

$25 \quad$ Ibid, pg. 115; See H. Ciereszko, Życie i działalność księdza Michała Sopoćki (1888-1975. Petna biografia apostoła Miłosierdzia Bożego, Cracow 2006, pgs. 383-384.

26 Ibid, pg. 115.

27 See M. Sopoćko, Wspomnienia, WKAB 14(1986), pgs. 114-115.

$28 \quad$ H. Ciereszko, Życie i działalność ks. Michała Sopoćki, op. cit., pg. 577; see also Sopoćko, Dziennik, pg. 34. 
the Director of Education and Fr. Adam Sawicki as the Capitular Vicar. Fr. Sopocko and laypersons played a huge role in preparing future catechists. All of Fr. Sopocko's efforts to prepare catechists testify to Bl. Michael Sopocko his sincere desire to deepen the faith of children and youth.

Fr. Sopocko's role duties as a spiritual director for religious was very important to him. After Archbishop Romuald Jalbrzykowski released Fr. Sopocko from his duties as a spiritual father of the Archdiocesan Major Seminary in Vilnius on August 26, 1932 and after the Ordinary Bishop Ordinary Bishop Jozef Gawlina released Fr. Sopocko from his duties as a military chaplain on August 30 of the same year and transferred Fr. Sopocko to the serve as a chaplain in the reserves, Fr. Sopocko did not cease his fervent pastoral work. Rather, he continued to serve in his pastoral role as an ordinary and extraordinary confessor for religious sisters and one order of lay brothers. Among the religious orders he served were: the Sisters of the Immaculate (without a habit), the Sister Servants of the Sacred Heart, the Missionaries of the Holy Family, the Ursulines, the Sons of Our Sorrowful Mother, the Bernardine Sisters, and the Sisters of Our Lady of Mercy (who Fr. Sopocko took under his spiritual care after he was released from his work at the seminary). ${ }^{29}$

For Sopocko began serving as the confessor for the Congregation of the Sisters of Our Lady of Mercy on January 17, 1933. This role was particularly significant for Fr. Sopocko because it was then that he met Sr. Faustina Kowalska, who wrote the following about Fr. Michael Sopocko in her Diary: "The week for confession came and, to my great joy, I saw the priest I had known before coming to Vilnius. [That is to say,] I had known him by seeing him in a vision. At that moment, I heard these words in my soul: This is My faithful servant; he will help you fulfill My will here on earth." ${ }^{30}$ Fr. Sopocko's encounter with Sr. Faustina initiated his apostolic work of spreading the message of Divine Mercy. He began this work by publishing articles and other longer essays on the topic. His publications on Divine Mercy are pastoral and show the importance of Divine Mercy in the liturgy, in witnessing to it in every day life, and particularly in pastoral work for the salvation of souls. After Fr. Sopocko met Sr. Faustina, publishing articles and essays became a particular feature of Fr. Sopocko's work and activities to promote Divine Mercy, which still requires close and detailed study.

$29 \quad$ M. Sopoćko, Wspomnienia, WKAB 13(1985) no. 4, pgs. 88-89.

30 S. M. Faustyna Kowalska, Dzienniczek. Miłosierdzie $w$ duszy mojej, Warsaw 1993, pg. 109, no. 263. 
Bl. Michael Sopocko

\section{Conclusion}

Bl. Michael Sopocko's zealous pastoral ministry was characterized by his broad range of interests. After the partition of Poland, he perceived a huge deficiency in pastoral ministry. Through his earnest involvement, he strove to remedy this lack by creating new pastoral institutions; catechizing adults, youth, and children in the truths of the faith by teaching them the Catechism; preparing members of the laity to teach religion; organizing small choirs for children and youth; and striving to connect people more closely to the Church. In his pastoral ministry, Fr. Sopocko also worked very hard to oppose alcohol abuse in every area of Polish society, but particularly among those living under the Russian occupation. He created and promoted movements in the Church such as: the Marian sodalities, ${ }^{31}$ Koła Inteligencji Katolickiej [The Catholic Intelligentsia Circle], and Catholic Action, among others. He did not try to avoid his military chaplaincy during the Polish-Soviet war. Fr. Michael Sopocko unquestionably demonstrated how much one fervent and faithful priest can achieve for the good of the faithful, the Church, and one's homeland.

\section{BŁOGOSŁAWIONY KS. MICHAŁ SOPOĆKO - GORLIWY DUSZPASTERZ}

Błogosławiony ks. Michał Sopoćko to postać fascynująca swoim zaangażowaniem i gorliwością we wszystkie dzieła, których dokonywał, a zwłaszcza te z dziedziny duszpasterskiej. Gdy zaś mówimy o bł. ks. Michale Sopoćce, o jego działalności duszpasterskiej i jego pracy naukowej to można rozróżnić trzy wyraźne okresy biograficzno-czasowe. Pierwszy okres obejmowałby jego życie w domu rodzinnym i praca w parafii Taboryszki aż do roku 1918, kiedy to wyjechał na studia do Warszawy. Drugi okres możemy rozciągnąć od powrotu do Wilna ze studiów, które miały miejsce na Uniwersytecie Warszawskim i trwały z przerwami od 1918 roku do 8 grudnia 1924 roku. Okres ten trwał aż do czasu zapoznania się z tajemnicą Miłosierdzia Bożego poprzez objawienia św. Faustyny w latach 1933-1934. W trzecim okresie działalności duszpasterskiej i naukowej ta tajemnica zdominowała jego poglądy zarówno na działalność Kościoła, jak i w ogóle na duszpasterstwo. Według tego schematu przedstawimy jego dokonania na polu duszpasterskim.

31 See S. Strzelecki, Sodalicyjne promienie Mitosierdzia w Biatymstoku, Bialystok 2006. 
Słowa kluczowe: dom rodzinny, wikariusz parafialny, studia uniwersyteckie, I wojna światowa, kapelan wojskowy, ojciec duchowny, profesor Uniwersytetu im. Stefana Batorego, spowiednik i wychowawca, budowniczy kościoła, kult Miłosierdzia Bożego, Wilno, Warszawa, Białystok.

\section{Bibliography:}

1. Ciereszko H., Życie i działalność księdza Michała Sopoćki (1888-1975. Petna biografia apostoła Miłosierdzia Bożego, Cracow 2006.

2. Kowalska F., Diary: Divine Mercy in My Soul, Stockbridge 2001, pg. 127, no. 263.

3. Sopocko M., Wspomnienia z przeszłości (Życiorys napisany własnymi stowami), WKAB 13 (1985) no. 2, pgs. 83-112.

4. Sopocko M., Wspomnienia z przeszłości (Życiorys napisany własnymi stowami), WKAB 13 (1985) no. 3, pgs. 97-123.

5. Sopocko M., Wspomnienia z przeszłości (Życiorys napisany własnymi stowami), WKAB 13 (1985) no. 4, pgs. 85-114.

6. Sopocko M., Wspomnienia z przeszłości (Życiorys napisany własnymi stowami), WKAB 14 (1986) no. 1, pgs. 97-123.

7. Sopocko M., Dziennik, oprac., wstęp i przyp. Henryk Ciereszko, Bialystok 2012, 2nd Edition.

8. Sopocko M., Centrum i peryferia, WAW 7(1933), pgs. 181-184.

9. Strzelecki S., Sodalicyjne promienie Miłosierdzia w Biatymstoku, Bialystok 2006.

10. Żdanuk T., Działalność abstynencka księdza Michała Sopoćki, WKAB 18 (1990) no. 1, pgs. 100-113. 